\title{
Self-Ignition Delay and Control Parameters of Diesel Engines for Different Vehicle Feeding Systems and Different Fuels
}

\author{
Wincenty Lotko ${ }^{1}$ \\ 1 Faculty of Mechanical Engineering, Kazimierz Pulaski University of Technology and Humanities in Radom, \\ ul. Chrobrego 45, 26-200 Radom, Poland \\ e-mail:w.lotko@uthrad.pl
}

\begin{abstract}
The phenomena accompanying the self-ignition period have been the subject of extensive research in this area. They are usually carried out in constant volume pressure chambers or in reactors with constant air flow. Such tests are considered to be basic. The conditions in these tests are definitely different from those in compression ignition engines. Therefore, the comparison of the auto-ignition delay periods from test setups to those obtained from real engines raises a number of doubts. Because the self-ignition delay period determines the combustion process, a theoretical analysis was conducted, pertaining to a number of factors that have an impact on this process which determines the operational aspects of the engine, and thus its economics and ecology. The research object was a single-cylinder engine from AVL LIST GmbH in Graz, Austria. The engine is equipped with a Common Rail injection system. The test setup meets the following standards: Directive 1999/96/EC of the European Parliament and the Council of $13^{\text {th }}$ December 1999, Regulation (EC) No 715/2007 of the European Parliament and the Council of $20^{\text {th }}$ June 2007, as well as Commission Regulation (EC) No $692 / 2008$ of $18^{\text {th }}$ July 2008. The analysis of the operational aspects of the self-ignition delay period was based on the results of tests on the AVL 5402 engine fueled with hydrocarbon fuels: diesel and synthetic oil. The engine was also fed with vegetable fuel - rapeseed oil. The obtained material from the tests warns the user of CI engines against the effects of their failure if the engine control parameters and the quality of fuel for its supply are not maintained as recommended by the manufacturers. The material contained in the publication is used for scientific analysis, and, which is worth emphasizing, is of a utilitarian nature.
\end{abstract}

Keywords: self-ignition delay; combustion process; fuel injection process; diesel engine, renewable fuels

\section{INTRODUCTION}

The condition for meeting the current requirements of compression ignition (CI) engine users is that the combustion processes should be carried out properly. The analysis of these processes for cognitive purposes is very difficult due to the simultaneous combustion and fuel injection processes, the phenomena of fuel injection and atomization from the air, evaporation of fuel droplets, chemical reactions and proper combustion process. In addition, we deal with with heterogeneity of the combustible mixture. In different parts of the combustion chamber, there are drops of liquid fuel alone, a mixture of fuel vapors with air and air only. During the entire combustion process in the chamber space, the excess air ratio has various values in different areas of its volume.

Self-ignition occurs most often when $\lambda=$ 0.8-0.9 and then the flame front spreads [19]. Self-ignition of hydrocarbons occurs after fuel injection into the combustion chamber. It is particularly important for the dynamics of the combustion process. In a CI engine, there is a short period of time to mix the injected fuel with the compressed air in the engine cylinder. Therefore, it is necessary to create such conditions where oxygen and atomized fuel droplets are close, which are prerequisite for fast ignition. The self-ignition delay process is influenced by a number of factors from the group of: chemical (mainly fuels), physical (external environment), construction (engine design) and operational (engine operation 
parameters) factors. In the publication, the author presents the factors of his own research on the impact of selected issues from the mentioned groups of factors on the self-ignition delay of a compression-ignition engine. The operational aspects of the engine in relation to the ignition delay period were taken into account $[7-9,12]$.

\section{The process of self-ignition delay}

The fuel injected into the combustion chamber undergoes a process of mixing with air and results in the evaporation process. This phenomenon is preceded by the chemical reactions related to the oxidation of hydrocarbons; as a result, the first self-ignition of the fuel-air mixture is formed. This order is due to the fact that the activation energy of fuel molecules for the evaporation process is many times smaller than for the oxidation.

The phenomena accompanying the self-ignition period have been the subject of extensive and current research in this field [3, 5, 11-13, 17, $19,21]$. The research is usually carried out in constant-volume pressure chambers or in reactors with constant air flow $[11,17,19]$. These tests can be included in basic tests, mainly concerning fuels. The self-ignition conditions in these tests are under constant control both as far as the initial fuel and air mixing and the fuel injection into heated, still air are concerned. These conditions fundamentally differ from the real ones in a CI engine, in which the air parameters (pressure and temperature in the cylinder) change due to the injection of diesel, hydrocarbon fuel with a different structure and volatility. Therefore, the comparison of the self-ignition delay periods obtained at test setups with those obtained from real internal combustion engines are the reason for doubts.

In a CI engine, self-ignition occurs when there is a heterogeneous temperature distribution and fuel concentration. The results of measurements carried out under such conditions may be ambiguous, which justifies the different opinions on this phenomenon presented by various researchers. Thus, a unified model of selfignition and combustion in $\mathrm{CI}$ engines has not been developed so far.

In an internal combustion engine, the processes of fuel injection, its evaporation, as well as vapor diffusion and exothermic and endothermic reactions occur simultaneously during the movement of the piston with its variable movement speed. The engine load, mainly the temperature of the sucked and compressed air, has an impact on the physical and chemical processes in the cylinder. Due to the nature of the phenomena occurring in the self-ignition delay process, two basic parts can be distinguished; physical $\left(\tau_{p}\right)$ and a chemical $\left(\tau_{c h}\right)$ one. The physical part includes the necessary time required for the injector to obtain a stream of fuel, its disintegration into small droplets, mixing with air and, consequently, heating and evaporating some of the fuel. The quality of fuel atomization has a significant impact on the physical period of self-ignition delay. The chemical part of the self-ignition delay period depends on the basic fuel properties or its components and takes place in the time necessary to complete the reactions before the first outbreaks of auto-ignition. For light hydrocarbon fuels, these reactions are relatively slow and have a multi-phase character. The self-ignition delay of these fuels can be described as a process that is affected by the changes in air-fuel pressure.

The chemical self-ignition delay period includes the time during which the heat resulting from the oxidation reaction between the fuel and oxygen vapors from the air will be released. This process leads directly to self-ignition. The duration of this period is determined by the tendency to disinegrate the hydrocarbon particle. This is a chain theory that assumes that self-ignition is the result of chain reactions when heat arises and an increase in temperature is a phenomenon where simple hydrocarbon-bonded chains are more easily disintegrated than polycyclic hydrocarbons.

Another concept, i.e. the thermal theory of self-ignition, assumes that high temperature is necessary to ensure effective particle disintegration $[10,21]$ in order to start chemical reactions and fuel self-ignition.

The data collected from the experiments by researchers for direct injection engines led to the development of a correlation formula to calculate the self-ignition delay expressed in by Hardenberg and Hase [4]. There are opinions that this formula may have a limited application for diesel fuel, but it cannot be used with vegetable fuels [19].

\section{Definitions of self - ignition delay}

This research subject is defined differently by the researchers who have carried out or are still undertaking work in this field. Some of them are listed below. 
- Ignition foci always appear after some time has elapsed since the beginning of the fuel injection. This time expressed in units of time is called the self-ignition delay period and is usually marked with the symbol $\tau_{s d}[19]$.

- The delay period (self-ignition delay), lasting from the beginning of the injection (usually determined on the basis of recording the moment of the injector needle lifting) until the beginning of the combustion process, which is accompanied by a collapse of the pressure curve (departure point of the combustion curve from the compression curve) [15].

- Self-ignition delay is the period of time that passes from the start of the injection to the appearance of a flame in the combustion chamber. In practice, due to the difficulties in determining the moment of flame appearance, the end of the delay is determined byan increase in pressure caused by the combustion - which is significantly easier to register - in relation to the combustion curve without fuel injection [18].

- Self-ignition delay is the time that passes between the beginning of the injection and the beginning of the combustion [1]. Selfignition occurs some time after the injection (i.e. self-ignition delay time dependent mainly on temperature and regardless of pressure. As it can be seen from the content of the definitions $1-6$, this phenomenon is defined by synonyms: the moment of selfignition delay, self-ignition delay, ignition delay. The author of this paper does not agree with the statement made by Brun R. [1], who, in his definition of the self-ignition delay period, thinks that it is a waste of time. It sounds as if everything should be done to eliminate it. The author of this publication estimates that the self-ignition delay period is a preparatory time when the preparation of the fuel-air mixture for the auto ignition takes place.

- Self-ignition delay period extends from the moment of the appearance of first droplets of fuel on the atomizer until the formation of the first auto-ignition foci [20]. In numerous publications, the end of the auto-ignition delay period is assumed to occur when there is a clear increase in pressure on the indicator chart (from the research). It should be underlined that this definition is not precise as it refers to the effect of occurring flame, not to the moment it appears.

- The author's definition of self-ignition delay: "self-ignition delay is the time from the beginning of the fuel injection marked with the first pressure drop in the injection line, to the point of a rapid increase in pressure on the indicator chart". This applies to the CI engines fed with Common Rail injection system; this is explained by the markings in Figure 1. This graphs refer to the working point of the AVL 5402 engine with load characteristics with $\mathrm{n}=1200$ $\mathrm{rpm}$ and torque $21 \mathrm{Nm}$. The pre-injection dose was $2.0 \mathrm{ml} /$ cycle, the pre-dose angle $-13.0^{\circ} \mathrm{CA}$, and for the main dose the angle was $4.0^{\circ} \mathrm{CA}$. The engine was powered by diesel fuel.

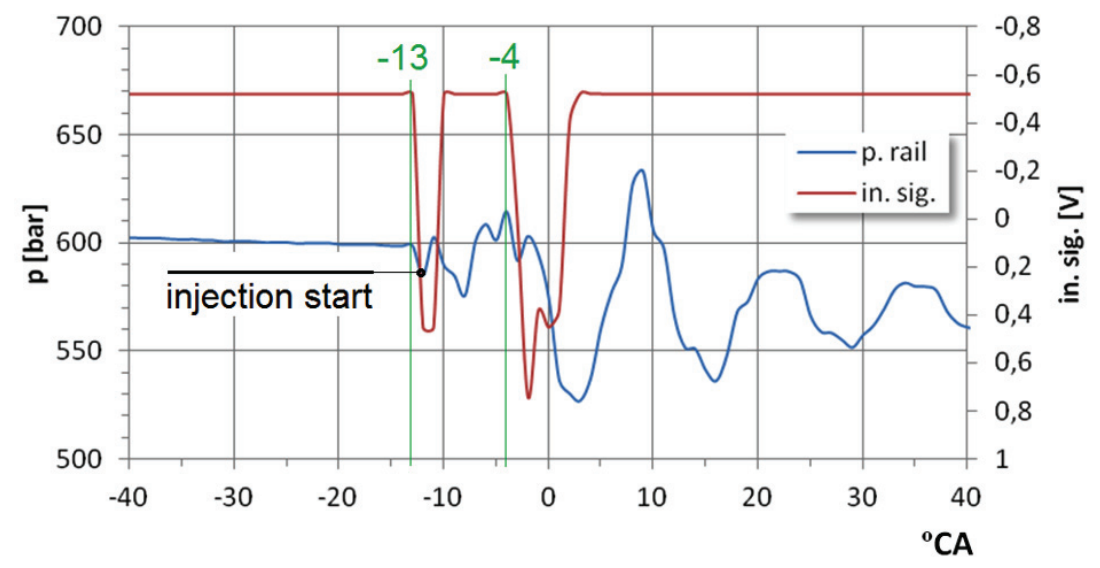

Fig. 1. Sample voltage and injection pressure signal waveforms necessary for the definition of the auto-ignition delay period and the course of the injector control voltage signal for one cycle, the fuel pressure course in the injection line between the header and the injector 


\section{The impact of selected factors on self-ignition delay}

Several basic factors have an impact on the self-ignition delay in a CI engine. These include:

- Chemical agents. The most important factor in this group that affects the self-ignition delay is the chemical composition of the fuel. The fuels containing large amounts of hydrocarbons of the olefin series, especially paraffin, are characterized by short periods of self-ignition delay. This is due to the easy disintegration of the fuel particles at the elevated temperature. The same factors determine the fact that values $\tau_{\mathrm{s}}$ are the lowest for normal paraffin hydrocarbons. Thus, the chemical structure of the fuel particles determines the period of self-ignition delay. The self-ignition delay period of the main diesel components, i.e. paraffin, petroleum and olefin hydrocarbons, decreases with the increase in the number of carbon atoms in the particle [14, 19, 21]. However, in the case of vegetable fuels and their esters, the period of self-ignition delay is determined by the structure of organic compounds included in these fuels. It was found that with an increase in the number of carbon atoms, the triglyceride volatility decreases due to the increase in their molecular weight, the viscosity and the surface tension increase [19, 14]. Consequently, these factors increase the self-ignition delay period. Other studies have shown that the self-ignition delay period decreases with the increase of linoleic acid content in natural vegetable oils [2]. The opposite relationships were found for fatty acid methyl esters. This was justified by their different physical and chemical properties. Methyl esters contain single chains in contrast to three chains of triglycerides.

- Physical factors. the temperature of the intake air to the engine has the most important impact on the self-ignition delay (for lower temperatures of the intake air the self-ignition delay is much higher, it is explained by the difficult start up of the engine) and the pressure at the end of the compression stroke (for higher pressures, the self-ignition delay decreases).

- Construction factors. From this group of factors, the type of combustion chamber, cylinder diameter, compression ratio, injection pressure, injector type and injection characteristics have the greatest impact on the self-ignition delay.

- Operational factors. The following factors should be distinguished: engine speed, coolant temperature, engine load, injection timing, combustion chamber tightness, excess air ratio, exhaust fume residue.

The following, important factors affecting the self-ignition delay were examined: fuel density, fuel viscosity, engine speed and engine load. The research concerned diesel fuel, synthetic fuel from the group of hydrocarbon fuels and rapeseed oil from the group of vegetable fuels.

\section{Selected physicochemical properties of tested fuels}

Two groups of fuels were used in the tests: diesel and vegetable fuels. The first group included: standard diesel fuel and its mixtures with synthetic fuel produced by EKOBENZ company. In detail, 5 and $10 \%$ by volume (v/v) of synthetic fuel were blended with diesel fuel and marked 5 OS ON and 10 OS ON, respectievly.

Synthetic fuel is an oil fraction as a mixture of hydrocarbons, mixing in any ratio with petroleum hydrocarbons. It is completely free of benzene, alcohols, sulfur, phosphorus and metals. The composition of this fuel is created by aromas, naphthenes and alkanes. The selected physicochemical properties of the tested fuels are given in Table 1 [16].

Table 1. Selected physiochemical properties of the tested fuels

\begin{tabular}{|c|c|c|c|c|c|c|}
\hline \multirow{2}{*}{ Parameters } & \multirow{2}{*}{ Units } & \multicolumn{4}{|c|}{ Hydrocarbon fuels } & \multirow{2}{*}{$\frac{\text { Vegetable fuels }}{\text { OR }}$} \\
\hline & & ON & OS & $5 \mathrm{OS}$ & $10 \mathrm{OS}$ & \\
\hline Density at $15^{\circ} \mathrm{C}$ & $\mathrm{kg} / \mathrm{m}^{3}$ & 837.0 & 907.0 & 844.0 & 845.0 & 920.0 \\
\hline Kinematic viscosity at $40^{\circ} \mathrm{C}$ & $\mathrm{mm}^{2} / \mathrm{s}$ & 2.48 & 2.50 & 2.48 & 2.49 & 34.56 \\
\hline Surface tension $\times 10^{-2}$ & $\mathrm{~N} / \mathrm{m}$ & 3.71 & - & - & - & 3.38 \\
\hline Cetane index & - & 51.90 & 18.0 & 50.0 & 49.0 & 38.0 \\
\hline Specific Energy & $\mathrm{MJ} / \mathrm{kg}$ & 43.80 & 42.71 & 42.84 & 42.80 & 36.9 \\
\hline Flash point & ${ }^{\circ} \mathrm{C}$ & 62.0 & 60.0 & 64.0 & 62.0 & $>300$ \\
\hline FAME content & $\%(\mathrm{~V} / \mathrm{V})$ & 7.0 & - & - & - & - \\
\hline
\end{tabular}




\section{RESEARCH OBJECTS AND TEST STAND}

For the detailed analysis of the phenomenon of self-ignition delay, a compression ignition engine was selected: a single-cylinder engine from AVL LIST GmbH in Graz, Austria. It is prof. Hans List's research centre of world renown. It carries out the research and construction works for new engines on behalf of car companies.

The AVL 5402 engine is equipped with a Common Rail fuel supply system and an electronically controlled injector. It has a two-phase fuel injection system with a pilot dose of fuel. The basic technical parameters of the AVL 5402 engine are given in Table 2. The diagram of the test setup with AVL measuring apparatus is shown in Figure 2.

Table 2. Engine characteristics

\begin{tabular}{|l|l|}
\hline Number of cylinders & 1 \\
\hline Bore & $85.01 \mathrm{~mm}$ \\
\hline Stroke & $90.00 \mathrm{~mm}$ \\
\hline Displacement & $511.00 \mathrm{~cm}^{3}$ \\
\hline Combustion type & Compression ignition \\
\hline Valve system & 4 valves \\
\hline Compression ratio & $17.0 \div 17.5$ \\
\hline Fuelling system & Common Rail \\
\hline $\begin{array}{l}\text { Maximum effective power, without } \\
\text { supercharging }\end{array}$ & $6 \mathrm{~kW}$ \\
\hline $\begin{array}{l}\text { Maximum effective power, with } \\
\text { supercharging }\end{array}$ & $16 \mathrm{~kW}$ \\
\hline Rated engine speed & $4200 \mathrm{~min}^{-1}$ \\
\hline Maximum injection pressure & $180 \mathrm{MPa}$ \\
\hline
\end{tabular}

\section{TEST RESULTS AND THEIR ANALYSIS}

Figure 3 shows the changes in the self-ignition delay period of hydrocarbon fuels dependent on the engine speed [16]. The AVL 5402 engine was powered by ON (diesel fuel), 5 OS ON (mixture of $5 \%$ of OS with ON) and 10 OS ON (mixture of $10 \%$ of OS with $\mathrm{ON}$ ), respectively.

The tested diesel fuel contained $7 \%$ by volume (v/v) of fatty acid methyl esters (FAME). The second fuel was synthetic diesel OS as the residual of the gasoline fraction from the liquid product of the process of catalytic conversion of alcohols to a mixture of hydrocarbons according to ETG technology (patent application P.408081) developed by the EKOBENZ company in Lublin. The engine was loaded with 3 parameters of speed characteristics. It can be seen from the graphs (Fig. 3) that the self-ignition delay angle of the tested fuels increases along with the rotational speed. The addition of OS fuels to the mixture causes a slight increase in the ignition delay angle. This is mainly justified by the lower cetane number of diesel fuel and consequently its mixtures with ON (Table 1). An increase in the engine speed causes an increase in the absolute combustion rate (turbulence, mass transfer, heat exchange increases). Higher rotational speed causes an extended combustion period. The increase in rotational speed shortens the self-ignition delay period, but linearly it extends in ${ }^{\circ} \mathrm{CA}$ in proportion to the increase in rotational speed.

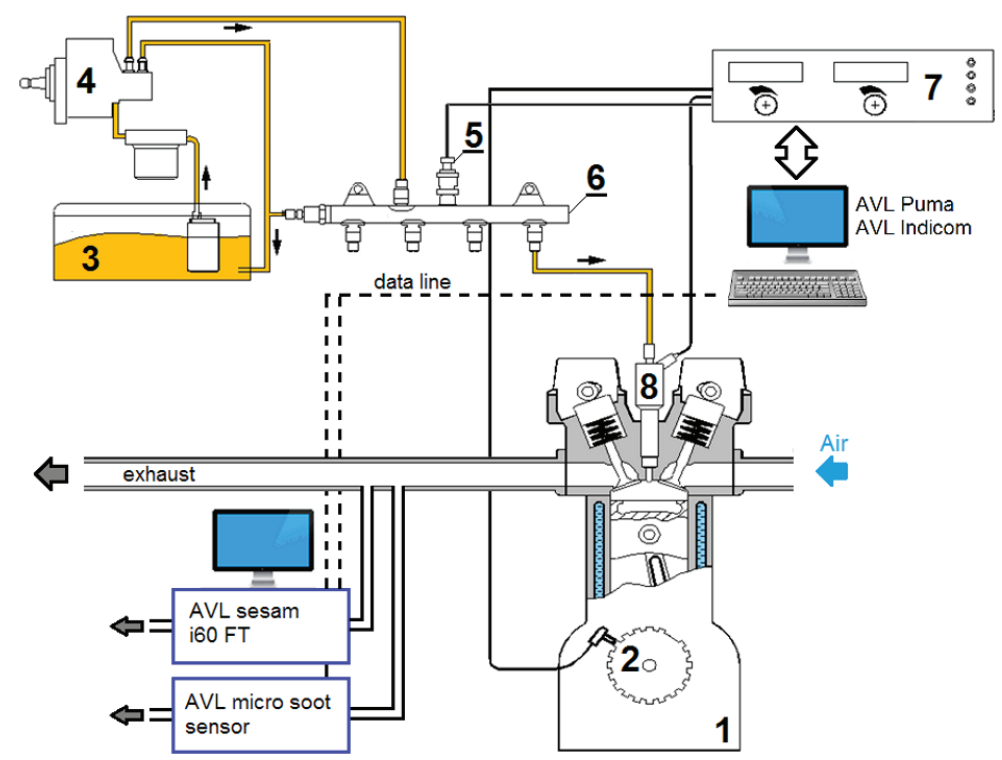

Fig. 2. General layout of test setup supply: 1 - engine, 2 - crankshaft speed sensor, 3 - fuel tank, 4 - high pressure pump, 5 - fuel pressure sensor, 6 - fuel rail, 7 - controller of Common Rail supply system, 8 - injector 


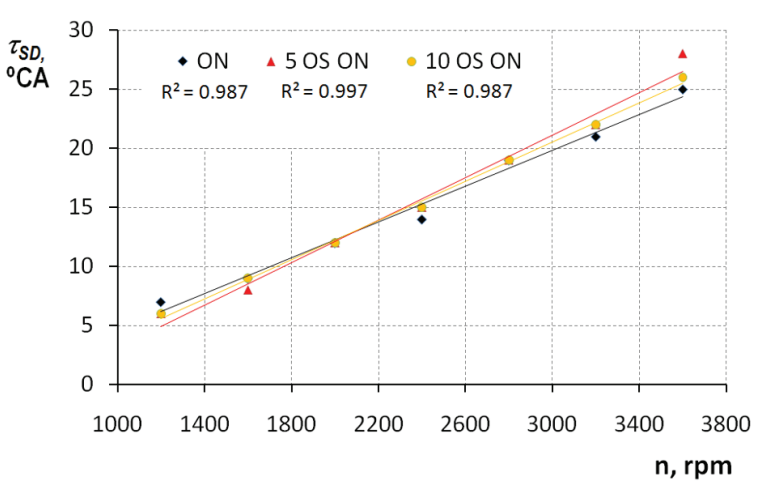

Fig. 3. Changes in the self-ignition delay process, depending on the rotational speed of the AVL 5402 engine powered by ON (diesel fuel) and its mixtures with OS (sunflower oil) for speed characteristics

The increase of the pressure rise rate in the combustion chamber $(d p / d \alpha)_{\max }$ is included in the engine operating parameters and this indicator increases together with the fuel dose injected into the combustion chamber. If this indicator exceeds $0.7 \mathrm{MPa} /{ }^{\circ} \mathrm{CA}$, the engine is noisy. Thermal and mechanical loads of the engine crank-piston system are also increasing. Figure 4 shows the relationship between the in-cylinder pressure rise rate and the angle of self-ignition delay. For this example of the engine load with its load characteristics, the values of pressure rise rate in the combustion chamber are within $0.30 \div 0.47 \mathrm{MPa} /{ }^{\circ} \mathrm{CA}$, the engine work can be classified as smooth.

The engine was powered by ON hydrocarbon fuels with the addition of synthetic diesel oil 5 OS ON and 10 OS ON. The synthetic oil fuel additions had a slight effect on the changes in the self-ignition delay angle in ${ }^{\circ} \mathrm{CA}$.

In turn, Figure 5 shows the relationship between the maximum combustion pressure $\left(p_{c}\right)_{\max }$, and

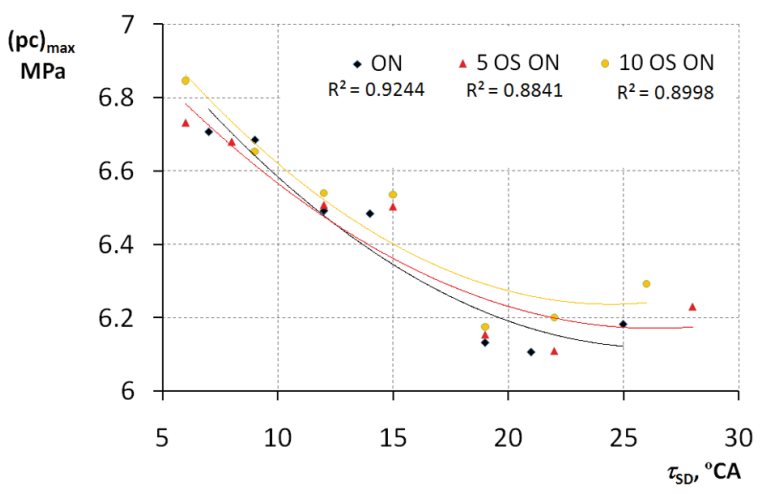

Fig. 5. Impact of the self-ignition delay angle $\tau_{\mathrm{ds}}$ on the maximum in-cylinder pressure values $\mathrm{pc}_{\max }$ for the tested fuels (AVL 5402 engine) for the speed characteristics; ON - diesel fuel, OS - sunflower oil

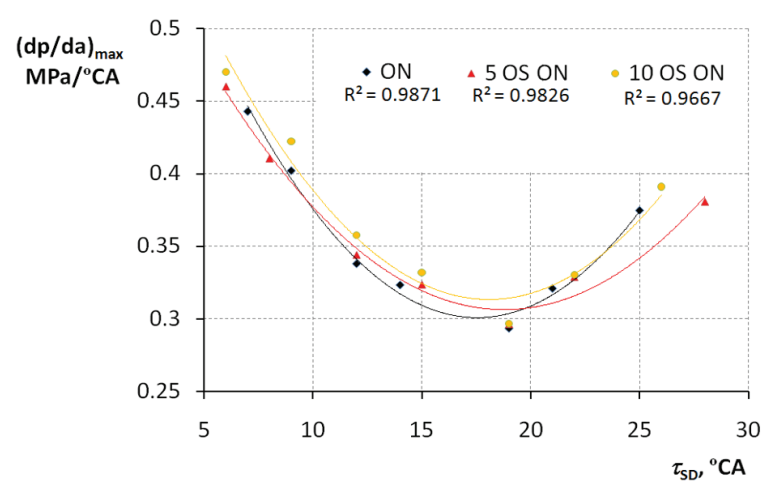

Fig. 4. Impact of the tested fuels on the in-cylinder pressure rise rate $(\mathrm{dp} / \mathrm{da})_{\max }$ depending on the selfignition delays (AVL 5402 engine) for the speed characteristic; ON - diesel fuel, OS - sunflower oil

the self-ignition delay period $\tau_{s d}$ for diesel and its mixtures with synthetic oil. The analysis of the graph shows that the maximum combustion pressure occurs for the self-ignition delay angles in range $6-8{ }^{\circ} \mathrm{CA}$. Higher values of $(p c) \max$ are obtained by the mixtures of ON with the addition of 5 and $10 \%(\mathrm{v} / \mathrm{v})$ of synthetic oil, compared with diesel fuel.

For the assessment of the influence torque, rotational speed of the AVL5402 engine on the self - ignition delay period $\tau_{s d}$ of diesel fuel and rapeseed oil the test result summary was presented (Fig. 6-8). From the analysis of these results it is clear that:

- an increase in rotational speed extends the self-ignition delay period for the tested fuels - DF and RO. The nature of the changes is similar for both tested fuels, the self-ignition delay period $\tau_{s d}$ for DF is slightly shorter than for rapeseed oil and clearly longer for higher speeds

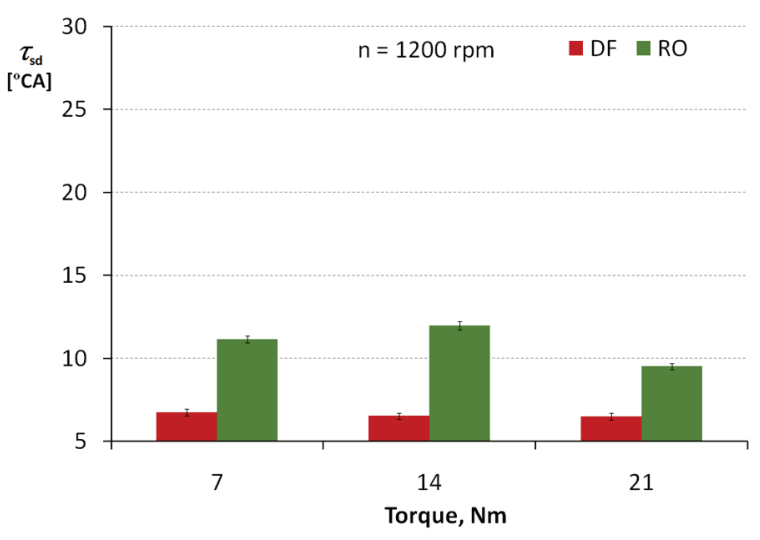

Fig. 6. Impact of engine load on self-ignition delay for diesel and rapeseed oil (AVL 5402 engine, $\mathrm{n}=1200 \mathrm{rpm})$; DF - diesel fuel, RO - rapeseed oil 


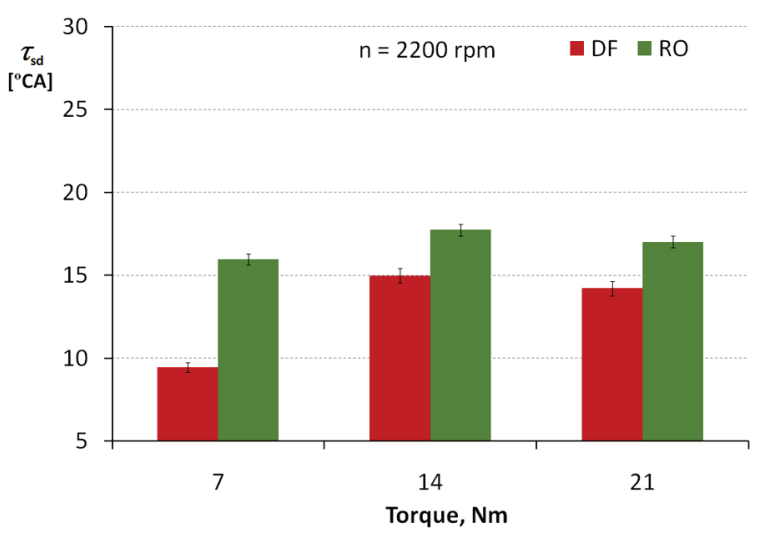

Fig. 7. Impact of engine load on self-ignition delay for diesel and rapeseed oil (AVL 5402 engine, $\mathrm{n}=2200 \mathrm{rpm}$ ); DF - diesel fuel, $\mathrm{RO}$ - rapeseed oil

- higher engine torque at low engine rotational speed does not affect the self-ignition delay period for diesel, and has a very low impact on rapeseed oil. A similar character of changes $\tau_{s d}$ was observed for the remaining engine speeds.

The further part of the analysis will concern the comparative tests of diesel and rapeseed oil as far as the impact of the engine rotational speed, its load on the maximum combustion pressure, the combustion pressure rise rate and the self-ignition delay period are concerned. The AVL 5420 engine worked on load characteristics at crankshaft speed: 1200, 2200 and $3200 \mathrm{rpm}$ and torque: 7, 14 and $21 \mathrm{Nm}$.

The conclusions drawn from the analysis are as follows:

- the increase of the engine rotational speed slightly reduces the self-ignition delay period in $m s$, but it extends this period expressed in ${ }^{\circ} \mathrm{CA}$,

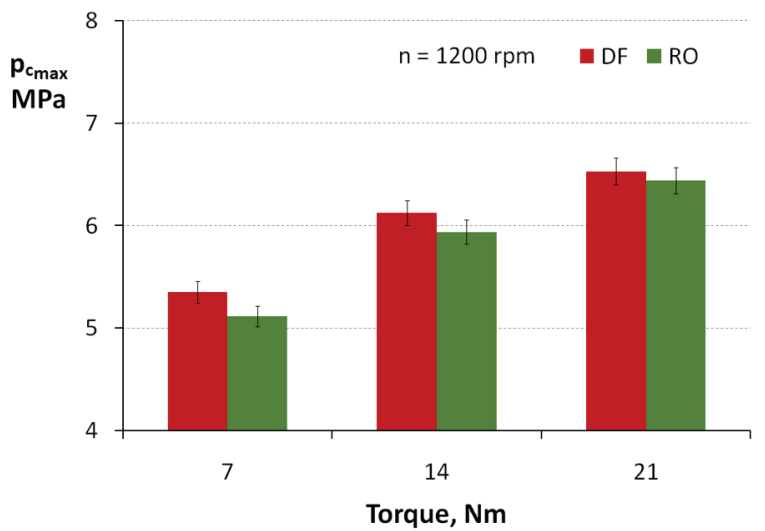

Fig. 9. Impact of engine load on the maximum combustion pressure for diesel and rapeseed oil (AVL 5402 engine, $\mathrm{n}=1200 \mathrm{rpm}$ );

$\mathrm{DF}$ - diesel fuel, $\mathrm{RO}$ - rapeseed oil

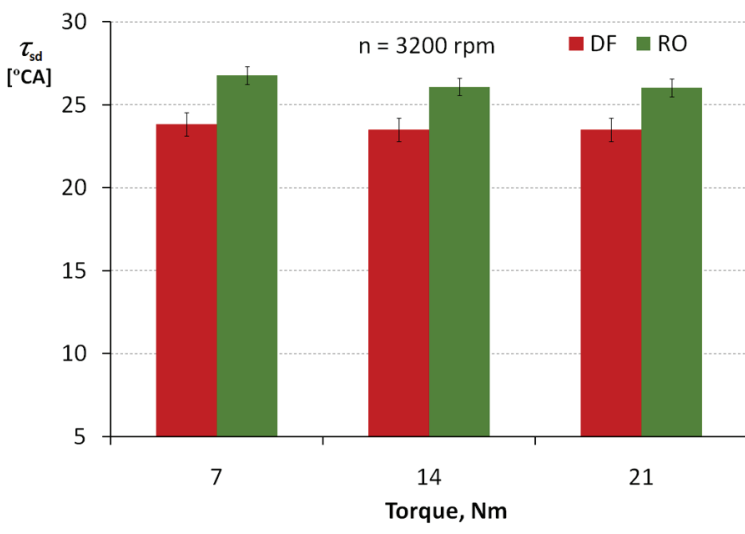

Fig. 8. Impact of engine load on self-ignition delay for diesel and rapeseed oil (AVL 5402 engine, $\mathrm{n}=3200 \mathrm{rpm})$; DF - diesel fuel, $\mathrm{RO}$ - rapeseed oil

- for the increase in torque and rotational speed, the self-ignition delay period is longer by approx. $3-5{ }^{\circ} \mathrm{CA}$ for rapeseed oil in comparison with diesel fuel,

- maximum values of combustion pressure increase along with the fuel dose. The combustion process depends on the physicochemical properties of DF and $\mathrm{RO}$ and a different organization of the combustion process due to the division of the fuel dose per cycle in the Common Rail system, in relation to the earlier fuel supply systems. It can be approximately assumed that the $(p)_{\text {max }}$ values are comparable between DF and RO (Fig. 9-11).

The in-cylinder pressure rise rate $(d p / d \alpha)_{\max }$ for diesel in the whole range of rotational speed and engine load ensured its smooth work. When the engine was fed with rapeseed oil, the AVL 5402 engine performance was rough with the exception of the engine load with a torque of $7 \mathrm{Nm}$ (Fig. 12-14).

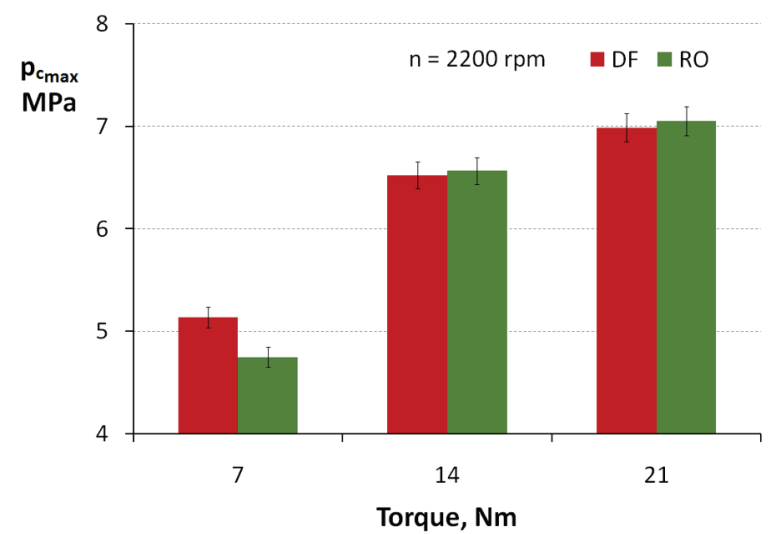

Fig. 10. Impact of engine load on the maximum combustion pressure for diesel and rapeseed oil (AVL 5402 engine, $\mathrm{n}=2200 \mathrm{rpm}$ ); $\mathrm{DF}$ - diesel fuel, RO - rapeseed oil 


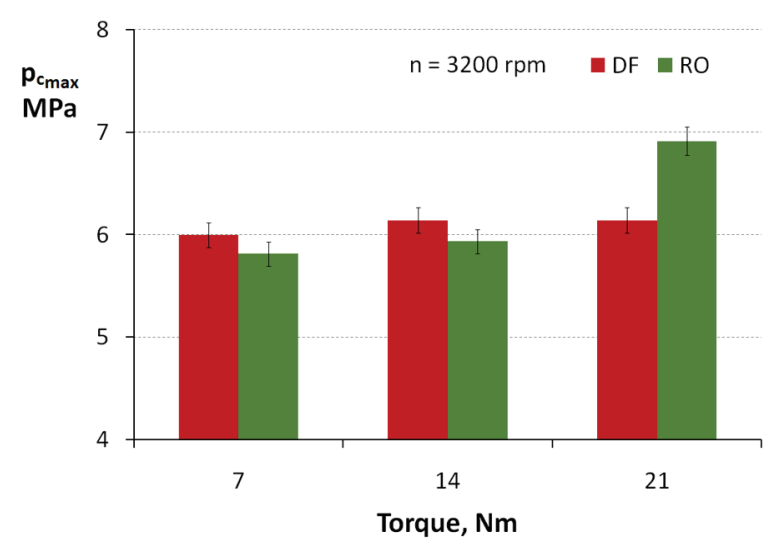

Fig. 11. Impact of engine load on the maximum combustion pressure for diesel and rapeseed oil (AVL 5402 engine, $\mathrm{n}=3200 \mathrm{rpm}$ );

$\mathrm{DF}$ - diesel fuel, RO - rapeseed oil

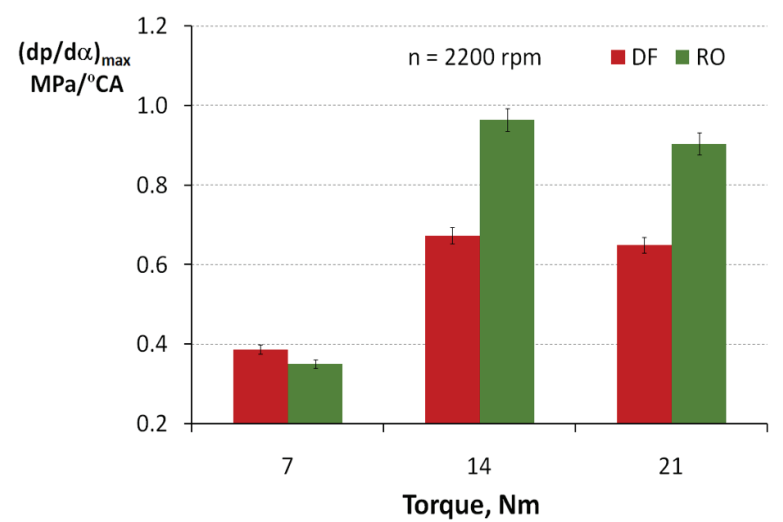

Fig. 13. Impact of engine load on the in-cylinder pressure rise rate for diesel and rapeseed oil (AVL 5402 engine, $\mathrm{n}=2200 \mathrm{rpm}$ );

$\mathrm{DF}$ - diesel fuel, $\mathrm{RO}$ - rapeseed oil

The self-ignition delay period for the presented tests was slightly higher for rapeseed oil than when the engine was fed with diesel. The results previously presented by other researchers and the author should be referred too. The combustion process in the AVL 5402 engine was completely different due to its being fed with a divided fuel dose per cycle. There were different procedures and stages in particular phases, which are known for combustion in a chamber of engines fed with the fuel in a traditional way.

\section{Operational aspects of the self- ignition delay period}

The extension of the self-ignition delay period may result in a high indicator of the increase in the pressure rise rate $d p / d \alpha$. Consequently, it may cause an excessive overload of the engine

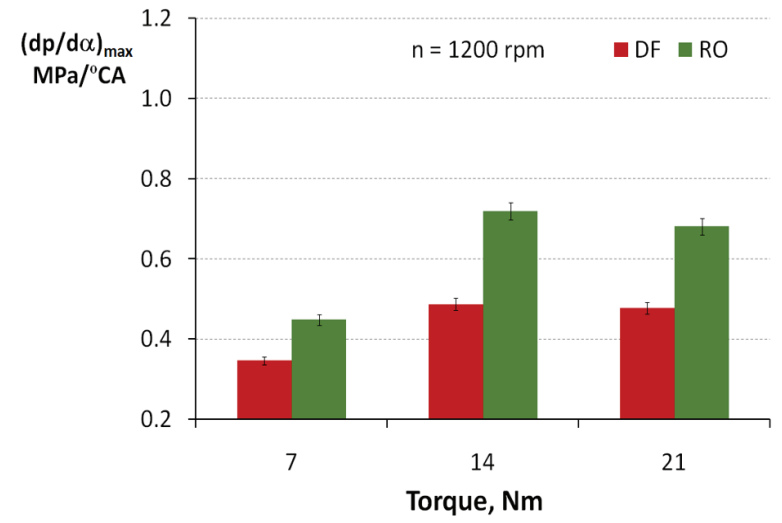

Fig. 12. Impact of engine load on the in-cylinder pressure rise rate for diesel and rapeseed oil (AVL 5402 engine, $\mathrm{n}=1200 \mathrm{rpm}$ );

DF - diesel fuel, RO - rapeseed oil

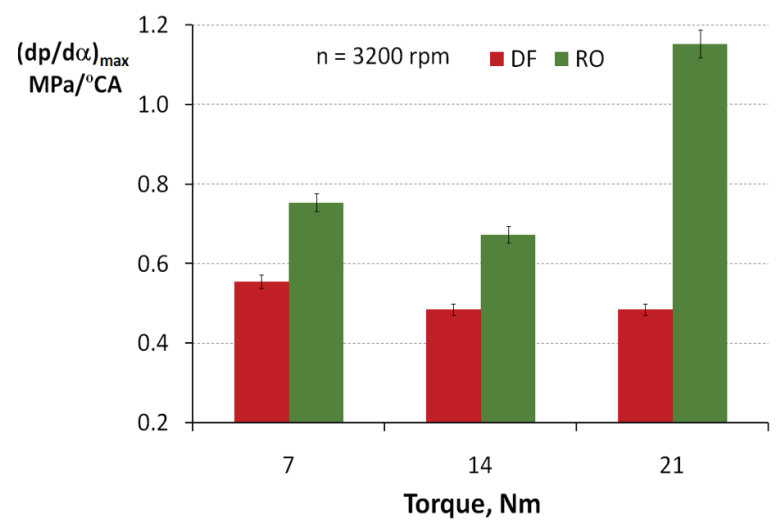

Fig. 14. Impact of engine load on the in-cylinder pressure rise rate for diesel and rapeseed oil (AVL 5402 engine, $\mathrm{n}=3200 \mathrm{rpm}$ ); $\mathrm{DF}$ - diesel fuel, $\mathrm{RO}$ - rapeseed oil

crank system components with the gas pressure forces. In case of disturbances in the combustion process, the injected fuel stream may be silted on the walls of the combustion chamber. If the wall temperature is low, fuel can flow into the oil sump, diluting the engine lubricating oil. At high wall temperatures, oil silts on them and it results in unburned fuel products in the form of soot, carbon deposit. Too long self-ignition delay period can cause a mechanical damage to the engine and decrease its efficiency. The increase in the selfignition delay may cause the fault as far as the engine start is concerned. During the engine startup, there is poorer fuel atomization due to its low rotational speed of about $400 \mathrm{rpm}$. Therefore, at this time, the physical part of the self-ignition delay period may be dominant. Similarly, this phenomenon may occur when using heavy crude oils or vegetable oils [19]. With a significant increase 
in the self-ignition delay, it can follow piston Top Dead Center (TDC), as a result of which more fuel will be accumulated in the cylinder. Consequently, there will be an excessive increase in the pressure rise rate $d p / d \alpha$ in the cylinder.

The degree of pressure increase in the combustion chamber can be influenced in a number of ways which have an impact on:

- fuel parameters, its atomic number,

- fuel injection parameters: an appropriate injection timing in relation to the self-ignition delay period, characteristics of the fuel injection pump output, an injector design,

- parameters of the combustion process by selecting the appropriate chamber and fuel injection system,

- operational parameters of the engine: temperature of the intake air, rotational speed in correlation with its load,

- technical condition of the engine, tightness of the combustion chamber system. The proper distribution of fuel in the combustion chamber is determined by two parameters: pressure rise rate $d p / d \alpha$ and maximum in-cylinder pressure $p c_{\text {max }}$.

The quality of fuel atomization has a decisive influence on the self-ignition delay $\tau_{\text {sd }}$. It determines the homogeneity of the fuel-air mixture. This is affected by the fuel supply system, including the type of atomizer and the fuel injection pressure. The injector opening pressure regulation should be strictly adhered to in accordance with the manufacturer's instructions.

The adjustment of the injection timing is also an important parameter. Too early injection can cause rough engine performance and even engine knocking. On the other hand, with too late injection, self-ignition may follow piston TDC. The combustion is transferred to the expansion stroke and causes overheating of the piston, rings and exhaust valves [20]. The air pressure in the cylinder, the fuel injection pressure and the injection timing should match the engine, depending on fuel properties.

Therefore, in order to ensure the adjustment of the self-ignition delay to the load and the rotational speed, automatic fuel injection adjusters are used in high-speed CI engines.

\section{CONCLUSIONS}

An analysis of the impact of a number of factors (mainly operational) on the self-ignition delay period of CI engines was performed. It was supported by sample test results for hydrocarbon fuels (diesel fuel, synthetic diesel fuel) and a vegetable fuel (rapeseed oil) used in Poland. It was confirmed that the self-ignition delay of rapeseed oil is extended in comparison with diesel fuel. It can be justified with lower cetane number of plant oil. Moreover, the analyzed material warns the users of CI engines against the consequences of their damages in case of failure to comply with the engine control parameters and fuel quality as recommended by manufacturers.

The conclusions from the analysis of auto-ignition delay for the AVL 5402 engine fueled with diesel fuel and rapeseed oil are as follow:

- increase in engine load and rotational speed extends the period of self-ignition delay for rapeseed oil compared to diesel oil,

- it can be assumed with some approximation that the values of the maximum combustion pressure $p c_{\max }$ are comparable for diesel fuel and rapeseed oil,

- the values of the in-cylinder pressure rise rate $(d p / d \alpha)_{\max }$ obtained for diesel fuel in the whole range of engine loads ensures its soft operation. When fed with rapeseed oil the engine work was rough in most of the load range.

When supplying the AVL 5402 engine with rapeseed oil and diesel, it was found that:

- higher $p c_{\max }$ values are obtained in the process of combusting a mixture of synthetic oil and diesel fuel compared to diesel fuel alone,

- the in-cylinder pressure rise rate $(d p / d \alpha)_{\max }$ increases along with the share of synthetic oil in the fuel dose.

- the auto-ignition delay angle increases along with the engine speed. The addition of OS fuel to diesel oil causes a slight increase in the auto-ignition delay angle proportionally to the increase in rotational speed.

The paper analyzed the influence of a number of factors related to a compression-ignition engine, mainly including the operating ones, on the period of auto-ignition delay. It was supported by exemplary results of the fuels tested. Extending the auto-ignition delay period may result in a high rate of pressure build-up and result in excessive loading of the engine crankshaft by gas pressure forces. As a consequence, it can lead to mechanical damage of the engine and decrease of its efficiency. Lengthening the auto-ignition delay period may prevent the engine from starting, 
where the dominant period is the physical part of the auto-ignition delay period. A similar phenomenon may take place when fueling the engine with heavy fractions of crude oil or vegetable oils.

Various engine fuels have a decisive influence on the delay period of auto-ignition. The period of self-ignition delay increases along with the number of carbon atoms in the fuel molecule. It was confirmed that the quality of fuel atomization has a significant influence on the delay of self-ignition. This is mainly due to the fuel supply system to the engine. The Common Rail fuel injection system replaces the existing mechanical systems of in-line pumps, unit injectors and distributor pumps without electronic control of fuel injection. Under operating conditions, the regulation of the injector opening pressure and the fuel dose should be strictly observed, in accordance with the manufacturer's recommendations. A similarly important parameter is the injection advance angle.

All the discussed issues related to the autoignition delay period acquire additional particular importance when using alternative fuels for compression ignition engines.

\section{REFERENCES}

1. Brun R. Szybkobieżne silniki wysokoprężne. WKŁ Warszawa 1973.

2. Goering C.E., Schwab A.W., Daugerty M.J., Pryde E.H., Heakin H., Fuel properties of eleven vegetable oils. Transactions of the ASAE, 1982, 25(6), 1472-1477.

3. Górski K., Smigins R., Longwic R. Research on physico-chemical properties of diethyl ether/linseed oil blends for the use as fuel in diesele engines. Energies, 13(24), 2020, 1-16.

4. Hardenberg H.O., Hase F. W. An empirical formula for computing the pressure rise delay of a fuel from its octane number and from relevant parameters of direct - injection diesel engines. SAE Transaction, 790493, 1979.

5. Heywood J. B. Internal Combustion Engine Fundamentals. McGraw-Hill, Singapre 1989.

6. Klimkiewicz M., Mruk R., Osiak J., Roszkowski H., Słoma J., Wojdalski J. Efektywność pracy silnika zasilanego olejem rzepakowym. Inżynieria Rolnicza, 2 (143), 2013, 123-132.
7. Kowalewicz A. Wybrane zagadnienia samochodowych silników spalinowych. Wydawnictwo WSI Radom, 1996.

8. Kowalewicz, A.; Lotko, W. Performance and same combustion characteristics of $\mathrm{CI}$ engines fueled with rape oil and its ester. 21st CIMAC Congress, Interlaken, Switzerland, 1995, Paper D 54.

9. Kowalewicz A., Luft S., Lotko W., Różycki A. Infuence of application of rope oil ester on combustion processes and performances of CI engines. 25 Symposium, California Imvine 1994.

10. Kowalewicz A. Combustion systems for highspeed, piston internal combustion engines. WKE, Warszawa 1990.

11. Kuszewki H., Jaworski A., Ustrzycki A. Badania właściwości samozapłonowych mieszanin oleju rzepakowego i napędowego. The National Transport University Bulletin: A Scientific and Technical Journal, 27, 2013, 169-174

12. Lotko W. Zasilanie silników wysokoprężnych paliwami węglowodorowymi i roślinnymi. WNT, Warszawa 1997.

13. Longwic R., Sondera P., Lotko W., Górski K., Jańczuk B., Zdziennicki A., Szymczyk K. Samozapłon mieszanin oleju rzepakowego $\mathrm{z} n$ heksanem w silniku o zapłonie samoczynnym. Przemysł Chemiczny, 2, 2020.

14. Longwic R., Sondera P., Nieoczym A., Lotko W., Krzysiak Z., Samociuk W., Bąkowski H. Effect of some properities of hydrokarbon fuels on self - ignition delay. Przemysł Chemiczny, 5, 2017, 1123-1127.

15. Luft S. Podstawy budowy silników. WKŁ, Warszawa, 2018.

16. Łodygowski K. Studium silnika spalinowego o zapłonie samoczynnym zasilanego mieszaninami mineralnego oleju napędowego $\mathrm{z}$ biowęglowodorami. Wydawnictwo PWSZw Koninie, Konin 2019.

17. Mruk R., Klimkiewicz M., Botwińska K. Research on the combustion process of diesel and crude rapeseed oil as an element of design selection. Logistyka, 5, 2015, $397-404$.

18. Niewiarowski K. Tłokowe silniki spalinowe. WKŁ, Warszawa 1983.

19. Szlachta Z. Zasilanie silników wysokoprężnych paliwami rzepakowymi. WKŁ, Warszawa 2002.

20. Wajand J.A. Silniki o zapłonie samoczynnym, WNT, Warszawa, 1993.

21.Zabłocki M. Wtrysk i spalanie paliwa w silnikach wysokoprężnych. WKŁ, Warszawa, 1976. 